\title{
Cross-Cultural Studies and Pragmatic Awareness
}

\author{
J Sapoetra \\ Faculty of Humanities, Universitas Bina Nusantara, Jakarta, Indonesia \\ jsapoetra@binus.edu
}

\begin{abstract}
In the world of language learning it is obvious that culture plays a very important role. Learning a language is inseparable from learning its culture. Not only that, language teachers must also be aware of some linguistic competence such as pragmatic awareness. Being an English teacher, for example, it is not enough to teach only the grammar part but also when and how to use it in the right situation and context. A lot of misconception and misunderstanding happen as a result of pragmalinguistic failure to understand the use of language in the appropriate context. This paper is trying to discuss how cross cultural studies and pragmatic awareness contribute to the success of language learning particularly English. There are some examples from different languages given as a comparison along with its discussion. The results show that both cross cultural studies and pragmatic awareness have significant roles in creating a successful and meaningful language learning.
\end{abstract}

Keywords: Cultural Studies, Pragmatic Awareness, Language Learning

\section{INTRODUCTION}

Pragmatic awareness is undoubtedly one of the key factors in a successful language learning. According to Schmidt [1] : "It is necessary to implement pedagogicalintervention on pragmatic issues". This is something that most language teachers neglect of or are not aware of. Pragmatic knowledge leads to pragmatic skills and pragmatic competence. One of the most critical issues in language learning today is whether or not language teachers include pragmatic competence in their teaching and learning process. Most language teachers are not aware of the importance of pragmatic knowledge and skill in addition to grammatical and linguistic competence. This leads to pragmatic failure and results in communication breakdown. ESL/EFL learning context.Aside from pragmatic competence, language teachers must also know cross-cultural pragmatic which will help them understand other cultures and norms better. Here is the definition of cross-cultural pragmatics [2].

It is interesting to point out that the term refers to language behavior which means that attitude, feelings, and certain expressions involved. In relation to pragmatic awareness, we also found pragmatic failure in communication.

The study is trying to investigate the differences in speech acts used by different people from different cultures. The objective is to show that cross-cultural awareness is very important in dealing with languages, especially in the world of pragmatics. The research is beneficial for language teachers as well as students who study linguistic or language. Future emphasis will be for teaching and learning process and how the approach is implemented. 


\section{LITERATURE REVIEW}

\subsection{Pragmatic Awareness}

According to Nouichi pragmatic awareness is:"the conscious thoughtful and obvious knowledge about the pragmatic rules and conventions that direct the appropriate use of language in different communicative situations" [3].

It means that being 'aware' that people coming from different culture convey message in different ways and strategies. Based on the definition, there are some key words: conscious, knowledge, pragmatic rules, appropriate, communicative. In other words pragmatic awareness is consciously built in the mind of language teachers and learners.

\subsection{Pragmatic Failure}

According to Nouichi cross-cultural pragmatic failure is:"failure to understand a speaker's intentions in intercultural communication" [3]. The possible sources for pragmatic failure are:

\subsubsection{Pragmatic Transfer}

L1 strategies of SAS performing is transferred into the L2 while communicating with people from different cultural background.

\subsubsection{Different Cultural Values}

One culture has different rule to judge whether a topic and the way to say it is proper/improper.

\subsection{Teachers and Teaching Materials}

They are the main sources of language descriptions and norms, proper/inproper usage. In different societies and different communities, people speak differently; these differences in ways of speaking are profound and systematic, they reflect different cultural values, or at least different hierarchies of values; different ways of speaking, different communicative styles, can be explained and made sense of in terms of independently established different cultural values and cultural priorities [4]. Anyone who has lived for a long time in two different countries knows that in different countries people speak in different ways - not only because they use different linguistic codes, involving different lexicons and different grammars, but also because their ways of using the codes are different. Some of these differences are so stable and so systematic that one cannot always draw a line between different codes and different ways of using the code; or between different 'grammars' and different 'ethnographies of speaking [4] Cross-cultural pragmatics is a cognitive, social and cultural perspective on language and communication'[4]. Kramsch (1986) ..." a growing awareness of the importance of pragmatic knowledge in achieving mastery of a second language" [5].

\section{METHOD}

The study used library research method. The researcher conducted an investigation regarding the topic of speech acts from different cultures. Then, the findings were compared 
with other cultures to see the similarities and differences. After that, the researcher made a list of utterances produced by different speakers along with their meanings. The results show that different cultures caused different language utterances in conveying the meaning.

\section{FINDINGS AND DISCUSSION}

\subsection{Findings}

The following are the findings of several speech acts and their differences in meaning:

Table 1. Speech Acts from Different Culture.

\begin{tabular}{|c|c|c|c|}
\hline No & Study & Target Learner & Speech Acts \\
\hline 1. & $\begin{array}{l}\text { Eslame-Rasekh } \\
(2005)\end{array}$ & - Persians & $\begin{array}{l}\text { - Apologizing } \\
\text { - Food offering }\end{array}$ \\
\hline \multirow[t]{2}{*}{2.} & Amaya (2008) & $\begin{array}{ll}\text { - } & \text { Japanese } \\
& \text { (Sukwiwat) }\end{array}$ & Expressing gratitude \\
\hline & & - Spanish (Garcés) & Accepting invitation \\
\hline 3. & Glazer (2009) & $\begin{array}{l}\text { - ESL learners from } \\
\text { ten different } \\
\text { countries }\end{array}$ & Dispreferred disagreeing \\
\hline 4. & Jie (2010) & - Chinese & $\begin{array}{l}\text { - Responding thanking } \\
\text { - Greeting } \\
\text { - Requesting } \\
\text { - Agreeing request/proposal } \\
\text { - Accepting } \\
\text { invitation/presents } \\
\text { - Negative responding to } \\
\text { requests/offers/invitations }\end{array}$ \\
\hline 5. & Nouichi (2015) & Algerian Arabic & Thanking, greeting \\
\hline
\end{tabular}

\subsubsection{Persians [6]}

Apologizing: Excuses, absence of time (rescheduling)

Ei dad, agha ma baz sharmande shodim, joone to aslan nemidoonam chera [Oh my gosh, Mr. We became ashamed again, to your soul I don't know at all why]

hamchin shod.Agha sharmandeh, fesharezendegihavasibara ma nazashte! [happened. Mr. I'm ashamed, pressure of life has not left any attention for me] 
Equal expression in American English:

Oh, my gosh! I'm so sorry. I completely forgot. Can we schedule another time to meet? (food) offering: forceful \& direct
A : Khahesh mikonam befarmaeed, ghabele shoma ra nadare.
[Please, help yourself; it is not of value compared to your value]
B : Kheyli mamnoon, man hame chiz khordam,
[Thanks a lot, I ate everything]
A : Ekhteyar darid, manke nadidam, bayad yek portogal bokhorid,portoghalash abdareh. [You have the authority, I did not see (you eating), you must have oneorange, the oranges are juicy]
B : Kheyli mamnoon, chashm
[Thanks a lot, on my eye (humble and respectful form of okay)]

\subsubsection{Japanese (Sukwiwat in [7])}

a. Japanes

Expressing gratitude: 'Thank you' does not sound sincere enough

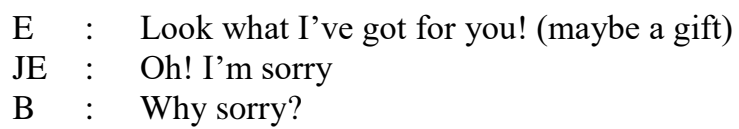

\section{b. Spanish (Garcésin [7])}

Accepting invitation:reluctance to accept an invitation to a party

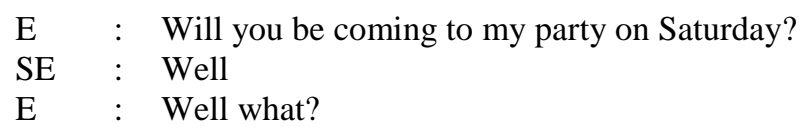

\subsubsection{EFL Learners From 10 Different Countries [8]}

Thedispreferred speech act of disagreeing

The limited variants and mostly blunt responses for expressing disagreement,

The "enfolded"(by preferred reactions) dispreferred S As

Oh, I thought I read it wasonly 50. Maybe I'm wrong. I'll have to check again.

Oh, I kinda liked it. Don't know what that says about me though!

\subsubsection{Chinese [9]}

Responding thanking: The use of "Never mind"

Chinese English learners usually utter it as the response to thanking, while in English, it is uttered to reply for the other interactant's apology, associated to consolation.

Greeting (topics) 
In Chinese, 'eating and whereabouts' topics are commonly found in greeting. In English, personal are avoided in opening conversation

Requesting: giving a hint or talking around the topic (face lost and face threatening)

A : Gosh, I'm out of money, I forgot to go to bank.

B : Sorry, I'd like to help you out, but I'm a little of cash myself.

A : Oh, I didn't mean I wanted you to lend me money.

Agreeing request/proposal: the non-verbalization and the absence of the necessity to inform time taken to complete a task.

In English, time information is provided, like;

Don't worry, I'll do it straight away!

It won't be a moment.

It may take about ten minutes. Would you care to wait?

- Accepting invitation/presents: a kind of refusal in accepting (to avoid the image of being eager or greedy)

- You should not have done it.

- It is too much work.

- It is too expensive.

- English, such expressions show real refusal that may cause embarrassment.

- Negative responding to requests/offers/invitations

In Chinese, the straightforward negative responses to requests, offers, or invitations is considered rude.

- Yes. (Meaning: Yes, I've received your invitations.)

- Thank you. (Meaning: Thank you for inviting.)

- Silence and smile. (Meaning: Thank you for your inviting.)

- In English, the avoidances could be interpreted "insincere", "devious" and "inconsiderate".

\subsection{Pedagogical Implications}

\subsubsection{The Cross-Linguistic Approach}

Culture should be taught in language class, with the objectives:

To get the students familiarwith cultural differences, to help the students transcend their own cultures and see things as the members ofthe target culture, to emphasize the inseparability of understanding language and understanding culture.

\subsubsection{Pragmatic Awareness Rising Activities}


The focus is learners acquire information about pragmatic aspects of language, by:

a. Exposing them to the L1 \& L2 language aspects

b. Providing them the analytical tools they need to arrive at their own generalizationsconcerning contextually appropriate language use

Information to acquire(for example):

a. Apologizing strategies used in the L1 \&L2

b. Consideration of the idea of offensive in the L1 \&L2

c. Different degrees of offence for different situations in the L1 \&L2

d. The nature of the relationship between the participants affects the use of apologies

\subsubsection{Improving Cross-Cultural Communication In Class}

Let learners have experiences with pragmatic investigation and analysis, particularly the negative transfers (failures), develop learners metapragmatic ability to study and discuss language use in a conscious manner in order to avoid cross-cultural failure. For intance, discussing explicitly the pragmatic parameters of a drama in class, particularly the characters' implied meanings, make learners aware about possible cross-cultural pragmatic differences between L1 \& L2

\section{CONCLUSION}

Cross-cultural pragmatic awareness is important for EFL learners for three reasons:

1. It benefits the learners to have adequate knowledge on how other culture apply their pragmatic competence.

2. It is needed to avoid miscommunication in the two or more different culture interaction.

3. Learning cross-cultural pragmatic will enable EFL learners to have wider perception in the patterns of language functions in communication.

The study tries to give ideas and contributions to the betterment of education system in Indonesia. The researcher realized that successful language learning will lead to successful education. Language teachers must have cross-cultural pragmatic awareness.

Raising cross-cultural pragmatic awareness can be applied through: teacherpresentation and discussion of research findings on different aspects ofpragmatics, student-discovery procedure, role play or drama.

\section{REFERENCES}

[1] E. Alcón and M. P. S. Jordà, "Pragmatic Awareness in Second Language Acquisition," in Encyclopedia of Language and Education, 2nd ed., New York: Springer Science Business Media LLC, 2008, pp. 193-204.

[2] I. Kecskes, Intercultural pragmatics. Oxford: Oxford University Press, 2014.

[3] F. Nouichi, "Cross-cultural pragmatic failure Expressions," Expression, pp. 95-101, 
2015.

[4] A. Wierzbicka, Cross-Cultural Pragmatics. German: Mouton de Gruyter, 2003.

[5] C. E. Davies, "Developing awareness of crosscultural pragmatics: The case of American/German sociable interaction," Multilingua - J. Cross-Cultural Interlang. Commun., vol. 23, no. 3, pp. 207-231, Jan. 2004.

[6] Z. Eslami-Rasekh, "Raising the pragmatic awareness of language learners," ELT J., vol. 59, no. 3, pp. 199-208, Jul. 2005.

[7] L. Fernández Amaya, "Teaching culture: is it possible to avoid pragmatic failure?," Rev. Alicant. Estud. Ingleses, no. 21, pp. 11-24, 2008.

[8] L. Fernández Amaya, "Teaching culture: is it possible to avoid pragmatic failure?," Rev. Alicant. Estud. Ingleses, no. 21, pp. 11-24, 2008.

[9] J. Fang, "A Study on Pragmatic Failure in Cross-Cultural Communication. Online Submission, 7(12), 42-46.," Sino-US English Teach., vol. 7, no. 12, pp. 42-46, 2010. 